\title{
Database Management Documentation
}

National Cancer Institute

\section{Source}

National Cancer Institute. Database Management Documentation. NCI Thesaurus. Code C115688.

Records pertaining to the management of a database for electronic data capture (EDC) in a clinical trial. 